\title{
A CASE OF TRAUMATIC MENINGOCELE; OPERATION, FOLLOIVED BY PERFECT RECOVERY.
}

\author{
BY Hnwarn LILIENTHal, M.D.,

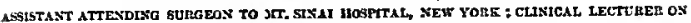 \\ SURGERY, XEW YORK POLYCtINIC, ETC.
}

Ox the 12th nf August, 1893, Jacoh F., four years old, was brought to my depnrtment of IIt. Sinni Dispensury to he treated for a swelling over the bnck of his head. Three weeks hefore he hnd fallen from a first-story wind ow and hnd sustained $\mathrm{n}$ scalp wound. The hoy was very dirty, and his hnir was natted nver a swelling as hig as a duck's egg, which was plainly fluctunting. It was a husy dny in the dispensary, so I gave the case to my assistant, Dr. D. D. Goldstein, for incision, thinking it $t n$ he nn ahscess under the scalp. Dr. Goldstein, having carefully shnved and scrubhed the part, noticed that something more than ordinary fluctuntion was present, nnd called my attention once more to the patient. On questioning the hoy's parents we then learned that he hnd heen for a ferw moments after the accident unconscious, hut that he quickly recovered himself and ran about as usual. He vomited once on thnt day, hut hnd no convulsion or other suspicious symptom. For nearly three weeks the hoy had heen well except that an enlargement at the hack of his hend had been slowly forming. For two dnys before he was hrought to me there had been persistent vomiting, hut no other aymptom. No chill nor fever had heen noted.

Exnmining the patient very carefully, the swelling was found to he of a thick snusnge shnpe, running from the most prominent part of the occiput to the left and down ward. It was fluctuating, softly pulsating, and could be pnrtly reduced. It became tense when the child cried. When partly reduced, one could feel a crevice in the hone extendiug vnguely in the direction of the swelling. A fine sterile hypodermatic needle was thrust into the tumor, and clear, non-nlbuminous fluid withdrawn, ahout thirty minims in all. The dingnosis of traumatic meningocele was now considered practically certain, nnd the patient was transferred to my service in the hospital. For the following two days the hoy's condition remained unchanged except thnt the vomiting tem. porarily ceased. The patient was irritahle and npprehensive, crying whenever one hut looked at him. On the 14th the tumor hnd hecome very tense, and the boy vomited his dinner, so three drachms of fluid were removed hy aspiration.

On August 17 th I operated. An incision was made nround the tumor in the shape of $n$ horseshoe, with the curve nhove and the pedicle helow. I tried tn separnte the sac from the scalp, intending then to cut off the redundnnt portion, suture the stump nnd return it to the craninl cavity. The sac was so very thin and so adherent, however, that it hurst at the first attempt. There was no shock, and the child hore the chloroform well, so the operation was continued. The fissure in the left pnrietal hone through which the meningocele protruded was now disclosed. It was ahout $n$ quarter of an inch in width, nnd hegan quite nhruptly ahout an inch th the left of the junction of the sagittal and lnmbdoid sutures, whence it extended dnwaward and to the left parallel with the margin of the occipital hone and toward the mastoid process of 
the temporal for two and a quarter inches. Here the edges of the crevice came together, and the break extended farther as a closed crack, the end of which I did not deem it necessary to see. Irooking into the fissure one could see apparently normal pia covering the hrain. With a small sbarp spoon $I$ removed that part of the meningocele sac whicb covered the edges of the fracture, and at the same time thoroughly scraped the hone from inner to outer tahle, so as to excite new boneformation. To protect the suhdural space from infection a strip of iodoformized gauze was tightly packed into the crevice and was hrought out at the left lower angle of the wound. The inner aspect of the scalp flap was now well scraped to free it from the adhereat sac, and was sutured back into its old place with catgut. After the operation, which lasted about half an hour, tbe patieat's pulse was 114, respiration 28 ; temperature $99.6^{\circ}$ There was some general collapse, which rendered necessary a stimulating enema of hot water and aa ounce of wbiskey. Nert day the boy's condition ras good. Higbest recorded temperature $99.2^{\circ}$. On the 20 th patient vomited his supper. His wound was dressed the first time five days after tbe operation, and tbe deep packing of iodo. formized gauze was removed through the angle of the wound. There was some stitch-hole suppuration, but not enough to iaterfere with the healing of the flap into its old position.

Subsequeutly the case progressed in an uaeventful manaer, and the boy was discbarged oa September 3d, apparently well.

On November 2, 1894, I again saw tbe little fellow, and tbere was a sound scar with not a trace of fissure or protrusioa.

I bave reported tbis case on accouat of its extreme rarity and to indicate a method of dealing witb such conditions.

The reason for the existeace of the meningocele I am uaable to give. Fracture of the skull is a common enough accideat, wbile traumatic meningocele is uncommor.

\section{LEAD GONVULSIONS.}

\section{A STUDY OF SIXTEES CASES.}

BY D. D. STEWART, H.D., LECTULEI ON MEDICISE IN THE IEFFERSOS SEEDCAL COLLEGE OF PHLADILIIA ; DIRECTOR OF TIIE STETSOS CLINICAL RESEARCIT LALOhATORY, ETG.

Tнат convulsions may arise in the course of chronic lead-poisoning appears to bave heen recognized from the earliest times. Ahout the middle of the seventeenth century, chiefly through the lahors of Stockbausen, whose practice lay in a region of lend mires and wbose acute observation led to the discovery of the cause of the "Poitou colic," wbicb had been previously described by Citois without its cause heing known, it became gradually recogaized that cerebral disorders accompanying lead-colic had similar origin. 